\title{
On the bleeding edge of farming the city: An ethnographic study of small-scale commercial urban farming in Vancouver
}

\author{
Sharla Stolhandske ${ }^{a}$ and Terri L. Evans ${ }^{b} *$ \\ Simon Fraser University
}

Submitted August 23, 2015 / Revised December 9, 2016 / Accepted January 23, 2017 /

Published online March 21, 2017

Citation: Stolhandske, S., \& Evans, T. L. (2017). On the bleeding edge of farming the city: An ethnographic study of small-scale commercial urban farming in Vancouver. Journal of Agriculture, Food Systems, and

Community Development, 7(2), 29-49. http://dx.doi.org/10.5304/jafscd.2017.072.010

Copyright (C) 2017 by New Leaf Associates, Inc.

\begin{abstract}
In this study, we explore the emergence and early development of small-scale commercial urban farming in metropolitan Vancouver, British Columbia. Commercial urban farming represents a grassroots entrepreneurial activity, spearheaded by individuals and groups, who combine the practices of growing and direct marketing fresh food products, in urban spaces for urban consumers. Considered as part of the agricultural renaissance occurring in cities and an example of the incremental shift toward more place-based food systems, commercial urban farming transforms

a Urban Studies Program, Simon Fraser University; $2^{\text {nd }}$ Floor, 515 West Hastings Street; Vancouver, BC V6B 5K3 Canada; sstolhan@alumni.sfu.ca

$\mathrm{b} *$ Corresponding author: Terri L. Evans; Urban Studies Program, Simon Fraser University; $2^{\text {nd }}$ Floor, 515 West Hastings Street; Vancouver, BC V6B 5K3 Canada;+1-778-782-7914; terri@sfu.ca
\end{abstract}

underutilized and unproductive land traditionally zoned for residential, commercial, or institutional use into intensive food-producing spaces.

Those pioneering this activity reported many benefits, including high job satisfaction, increased health and wellness, and making positive contributions toward the environmental health of the planet. Despite these advantages, they also faced many challenges in moving this model forward, including a lack of land tenure, low financial return, and the challenge of earning a living solely from farming activities.

We employed an ethnographic methodology to assess the practice, opportunities, challenges, and responses associated with this emergent model of urban food production and retailing. In capturing the lived experience of growers over a five-year period, we are also analyzing and understanding how and why the very first innovators trying to move this model forward in metropolitan Vancouver are negotiating and staking claim to 
new spaces in the city for intensive food production. We are also interested in why these early adopters were choosing to make their lives through pioneering small-scale commercial enterprises and systems, and creating and engaging in new forms of work connected with the local food economy.

\section{Keywords}

Commercial Urban Farming; Urban Farmers; Urban Agriculture; Vancouver; Local Food Economy

\section{Introduction}

We use this study to support two claims. The first claim is that a more comprehensive analysis of the economic realities of small-scale commercial urban farming is needed to better understand why some enterprises flourish while others flounder, and to determine how and if these commercial enterprises can become financially self-sustaining over the long term. Secondly, we assert that further research is needed to explore the degree to which these enterprises can move beyond the narrow white, middle-class demographic that largely initiates and supports local food and alternate food networks (Newman, 2008; Vickery, 2014).

Local food is enjoying a modern-day renaissance in our cities; many factors help explain this. According to Evans and Miewald, the growing local food movement reflects public concerns about "food safety and quality, the need to protect farmland from the impacts of suburban and exurban development, and [is] complemented by questions about how growing cities and regions will feed themselves" (Evans \& Miewald, 2010, p. 130). The resurgence of local food is also aided by an intergenerational interest: "the younger generation is looking forward with an eye toward food security and nutrition concerns, while the older generation is reclaiming memories, meaning, and tastes from previous decades" (Ackerman-Leist, 2013, p. 3).

The most visible expression of this burgeoning local food movement is seen in the explosion of farmers markets, community and rooftop gardens, public orchards, and edible trails that find increasing presence within our urban environments. They represent an interest by a subset of urban residents in eating food grown closer to home, food that represents somewhere - a particular terroir - where the distance between farm (or garden) and plate is greatly reduced, and one where the relationship between consumer and producer is valued and prioritized.

To address this growing interest in local food, individuals and groups in metropolitan Vancouver saw an opportunity to diversify and deepen the production and marketing of local food to urban consumers. Moving beyond the casual call to "eat your lawn," challenging the disconnect between urban agriculture and economic activity, and reimagining where farming may take place (i.e., a rural activity extended into urban space), these grassroots entrepreneurialists established smallscale commercial urban farming enterprises in atypical city spaces_-on land traditionally zoned for residential, commercial, and institutional use. This was no easy task as many of the urban farmers studied faced challenges related to resource mobilization and related constraints (financial, human, time, land).

It is the experience of these "urban farmers" in creating new spaces in the city for intensive food production, and who are pioneering new forms of work connected with the local food economy, that forms the basis of our case study.

\section{Background}

Small-scale commercial urban farming is a growing area of research and practice within urban agriculture in general, and the local food economy in particular.

The local food economy is an economy that supports the re-localization and socialization of food production, distribution, and consumption (Jarosz, 2008) and is built on the desire for local, fresh, organic, and specialty foods (Blay-Palmer \& Donald, 2006). Its attractiveness is evident in the "demand for food production-consumption chains that involve trust and transparency" (Blay-Palmer \& Donald, 2006, p. 391) and the resultant social connections between producer-consumer transactions that develop as a result (Hinrichs, 2000). For small-scale farmers, local food networks provide a niche market within which large-scale, global 
agribusinesses cannot compete, and allows the farmers greater profitability through direct marketing and value-added production than is achieved through traditional marketing pathways (Alden, 2008). Therefore, local food networks reflect placebased responses to the pervasive, yet unsustainable and increasingly risky, global food economy-one that disconnects place, and producer-consumer relations, in order to make food from anywhere available everywhere.

There appears agreement in the literature of Kaufman and Bailkey's early observation that those leading the for-market city farming movement, as they named it in 2000 , include a diverse collection of individuals and groups. These include, "community gardeners, community development corporations, social service providers, faith-based organizations, ...coalitions for the homeless, farmers with a special interest in urban food production, and profit-making entrepreneurs," among others (Kaufman \& Bailkey, 2000). These "early adopters" of what Newman (2008) later characterized as "extreme local food" provide "an array of social, aesthetic, health, and community-building benefits" (Kaufman \& Bailkey, 2001, p. 3), thus attracting more activity and attention in this field and to this work. The attraction to and importance of urban farming lies in "conventionally unacknowledged forms of value" in that "people who cultivate urban land to supplement their income, feed neighbors or build job skills create economic value that purely commercial farming does not. They are also place makers" (Vitiello \& Wolf-Powers, 2014, p. 520). This point reinforces an insight raised by Cohen and Reynolds (2015) that for many urban agriculturalists, urban farming represents a multifunctional activity, embedding a variety of goals (economic, environmental, community development, social justice), and expressed not only in the cultivation of food, but also in the related activities and programs connected with it.

Yet, despite these advantages, many scholars also underscore that small-scale commercial urban agriculture carries many burdens in meeting these wider objectives. The challenges are well identified across numerous studies, and include: agricultural knowledge and skills deficits among growers, high start-up and operating costs, concern around the potential exploitation of labor, insufficient access to land, issues relating to land tenure, seasonal and scale limitations on production, soil contamination and remediation, engaging residents, and local government impediments, among others (Angotti, 2015; Newman, 2008; Vickery, 2014). More recent scholarship also questions civic intentions around urban agriculture initiatives and the degree to which they help municipal governments "[perform] sustainability without addressing who actually benefits" (McClintock, Miewald, \& McCann, in press).

There is much potential to increase food production in urban areas, including in cities where land costs are high, as they are in our case study site. For example, Angotti draws on city planning data to reveal that in New York City, land that could be activated for urban agricultural production could be found in residential backyards $(20 \%$ or more of the land base), city parks (14\%), and through "reclaiming portions of the city's street and sidewalks, which account for $25 \%$ of all land" (Angotti, 2015, p. 337). Similarly, in the city of Vancouver, the central and most populous city within the metropolitan Vancouver region, studies have long highlighted where additional space for growing food and increasing local food access could be found. For example, as early as 2001, a study conducted by City Farmer estimated that at least one third of the land space in each standard Vancouver block could be used to grow food. The value was potentially much greater if paved surfaces, balconies, and decks were used (Houston, 2001; Levenston, Blecha, Schendel, \& Houston, 2001) and if rooftop gardens emphasized food production over ornamental uses (Davis, 2002; Kaethler, 2006).

While Vickery (drawing on conclusions reached by Virtiello and Wolf-Powers), highlights that "the most successful [urban farming] projects are mission-based and includes multiple goals outside of simply growing food for sale" (2014, p. 16), this study examines a different trend. In metropolitan Vancouver, British Columbia, individuals and groups are pioneering small-scale commercial urban farming as a new form of work connected to the local food economy, and on land not zoned for this activity. There is value in pro- 
viding " "thick' descriptions of local practices," according to Angotti, as these "inform the needed dialogue on urban agriculture policy among the public health, food, land use, zoning, environmental planning and economic development sectors" (Angotti, 2015, p. 337). The site of our study is metropolitan Vancouver (see Figure 1), a region that comprises 21 municipalities and one unincorporated area and, at 2.3 million people, represents the third largest city-region in Canada (B.C. Stats, n.d.-a).

\section{Study Methodology}

When this research study was first initiated in 2008, individuals and groups operating small plot, intensive, commercial enterprises on land not zoned for agricultural production in metropolitan Vancouver, were virtually unknown. To capture research participants, a snowball approach was employed. Media searches of local newspapers, blogs, and the websites of local urban agriculture organizations were conducted. Extensive networking within metropolitan Vancouver's urban agriculture and local food scene (for example, with vendors at Vancouver-based farmers markets and businesses associated with commercial urban growers, such as restaurants and edible landscaping consultants) helped identify contacts who could then provide connection with and referral to other contacts. This approach proved useful in identifying urban farmers, and in sufficient numbers (eight), to conduct this study.

There were a number of ways in which these urban farm operations were different from other

\section{Figure 1. Metropolitan Vancouver}

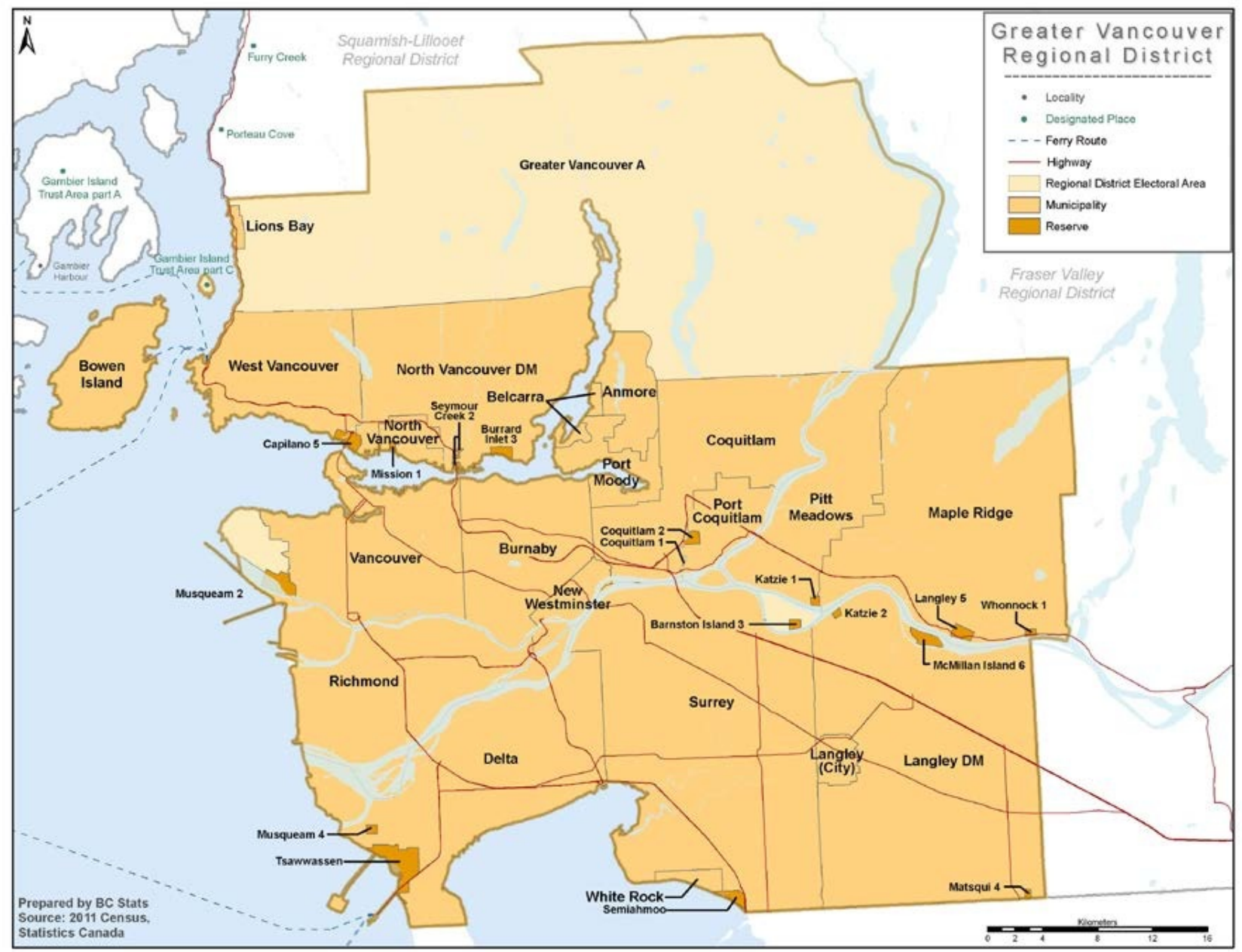

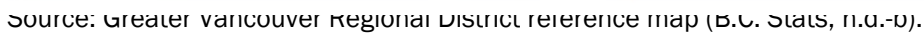


forms of farming taking place within the metropolitan Vancouver region. Five criteria in particular helped delineate urban farming enterprises:

1. The urban farmers grew and sold mostly food products;

2. The urban farmers produced all of their products in the city where they lived, without relying on imports to supplement their markets;

3. The urban farmers sold their products predominantly (if not exclusively) in urban markets in the same city;

4. The urban farm was established on land recently transformed from urban residential, commercial, or industrial use to agricultural use; and

5. The urban farm operated as a private enterprise, with the intention to make a living from the farming activities.

To test these assumptions, and ensure any potential study participants were not being overlooked, we overlaid these five criteria against the 2618 urban farms in metropolitan Vancouver, as identified in the 2006 Census of Agriculture. Criterion one eliminated potential commercial urban farming operations, such as the commercial greenhouses in Burnaby, located in the "Big Bend Area" on Marine Drive. These operations grew a significant amount of bedding and nursery plants in addition to food products. Criteria two and three eliminated farming operations integrated into existing food distribution channels; for example, a restaurant that sources most of its produce elsewhere but might grow specialist herbs or vegetables that cannot be easily obtained in local markets. Criterion four eliminated a number of urban farms which were part of the Agriculture Land Reserve (ALR), as this land has historically been used for agricultural purpose. Most urban farms in the ALR are only urban in the sense that some sections of the ALR fall within the administrative jurisdiction of a Metro Vancouver member municipality; not now nor at any time in the past have these lands been used for urban activities. Examples of these urban farms can be found in Richmond between No. 5 and No. 6 Road south of
Westminster Highway. An exception is Southlands in Vancouver, where the land is designated as ALR, but has been used more recently for urban residential purposes. Criterion five eliminated a wellknown urban farm in Vancouver, UBC Farm, as their agricultural activities center primarily on education, with the marketing of produce grown onsite being a secondary activity (UBC Farm, n.d.). When tested against the five criteria, all 2618 urban farms identified in the 2006 Census were eventually eliminated, and generated no additional research study participants.

Through applying these various methods, and especially the snowball effect, we determined that there were eight urban farms in operation across the region, and concentrated primarily in the cities of Vancouver and Richmond. Of these, seven individuals and groups were approached to participate in the research study, and of these, six were recruited (see Table 1 and Figure 2). The eighth individual identified was subsequently dropped as there were questions about their fit with the criteria.

The urban farmers and leaders of the farm groups were then contacted with requests for interviews and to arrange times where direct and participant observation could take place. The number of interview and observation sessions per farmer or farm group ranged from three to 10, depending on the size of the group and farmer availability over the 2009 growing season. Each session ranged from one to four hours in length and took place across multiple locations (e.g., farm sites, marketing venues). Notes were taken both during the sessions (as feasible) and following the sessions. These were then transcribed to record both manifest data (data that emerged through direct conversation and direct observation) and latent content (observations and points from conversations that would require further understanding and meaning). As the notes were coded and recoded, themes began to emerge, and a portrait of the farmers took shape, one which explored their background and history, marketing and/or selling approaches, land use issues, business practices, and planting regime. Convergent and divergent themes were then identified. The confidentiality of the urban farmers was important. Since this was a small group of farmers 
Table 1. The Urban Farmers

\begin{tabular}{|c|c|c|c|c|c|c|}
\hline $\begin{array}{l}\text { Farmer / } \\
\text { Farm Group }\end{array}$ & $\begin{array}{l}\text { Number of } \\
\text { Farmers } \\
\text { Involved in } \\
\text { Organization }\end{array}$ & $\begin{array}{l}\text { Year of } \\
\text { Operation in } \\
2009\end{array}$ & $\begin{array}{l}\text { Primary Food } \\
\text { Products Grown }\end{array}$ & $\begin{array}{l}\text { Type of Land Farmed and Approximate } \\
\text { Total Size }\end{array}$ & Marketing Products & Land Tenure \\
\hline $\begin{array}{l}\text { Eva's farm } \\
\text { group }\end{array}$ & 5 & First year & $\begin{array}{l}\text { Vegetables, } \\
\text { herbs, flowers }\end{array}$ & $\begin{array}{l}\text { Front lawn of institutional } \\
\text { property, } 10,000 \mathrm{ft}^{2}\left(929 \mathrm{~m}^{2}\right)\end{array}$ & $\begin{array}{l}\text { Farmers markets, } \\
\text { Harvest share }\end{array}$ & Borrowed \\
\hline $\begin{array}{l}\text { Marivec's } \\
\text { farm group }\end{array}$ & 3 & Second year & $\begin{array}{l}\text { Vegetables, } \\
\text { fruits, herbs }\end{array}$ & $\begin{array}{l}\text { Backyards in residential area, } \\
3 \text { sites, } 3,000 \mathrm{ft}^{2}\left(278 \mathrm{~m}^{2}\right)\end{array}$ & $\begin{array}{l}\text { Harvest share, } \\
\text { Farmers markets }\end{array}$ & Borrowed \\
\hline Frieda & 1 & First year & $\begin{array}{l}\text { Vegetables, } \\
\text { fruits, herbs }\end{array}$ & $\begin{array}{l}\text { Front and back yards in } \\
\text { residential area, } 2 \text { sites, } \\
3,200 \mathrm{ft}^{2}\left(297 \mathrm{~m}^{2}\right)\end{array}$ & $\begin{array}{l}\text { Harvest share, } \\
\text { Farmers markets }\end{array}$ & $\begin{array}{l}\text { Borrowed, } \\
\text { Co-owned }\end{array}$ \\
\hline Nazanin & 1 & Fourth year & $\begin{array}{l}\text { Vegetables, } \\
\text { herbs }\end{array}$ & $\begin{array}{l}\text { Front, back yards, patios in } \\
\text { residential area, } 13 \text { sites, } \\
8,000 \mathrm{ft}^{2}\left(743 \mathrm{~m}^{2}\right)\end{array}$ & $\begin{array}{l}\text { Harvest share, } \\
\text { Farmers markets }\end{array}$ & Borrowed \\
\hline Sabine & 1 & Second year & $\begin{array}{l}\text { Vegetables, } \\
\text { herbs }\end{array}$ & $\begin{array}{l}\text { Front and back yards in } \\
\text { residential area, } 7 \text { sites, } \\
3,000 \mathrm{ft}^{2}\left(278 \mathrm{~m}^{2}\right)\end{array}$ & $\begin{array}{l}\text { Harvest share, } \\
\text { Farmers markets }\end{array}$ & Borrowed \\
\hline Kim & 1 & First year & $\begin{array}{l}\text { Vegetables, } \\
\text { herbs }\end{array}$ & $\begin{array}{l}\text { Front and back yard in } \\
\text { residential area, } 400 \mathrm{ft}^{2} \\
\left(37 \mathrm{~m}^{2}\right)\end{array}$ & Harvest share & Borrowed \\
\hline
\end{tabular}

on the bleeding edge ${ }^{1}$ of a movement to grow and market local food in highly urbanized environments, a number of actions to protect the farmers and ensure anonymity were implemented. For example, all names used are pseudonyms and denoted with the pronoun "she" so to not reveal their individual identities. We then contacted these same farmers five years later with follow-up surveys and interviews to assess how their work had changed over time, and what factors informed their current practice; all but one of them participated in these activities.

\section{Main Themes}

In this section, we explore the main themes which emerged from the data gathered. These include the urban farmers' motivations, access to land, growing techniques and practices, marketing strategies, and revenue and/or income generation schemes.

\footnotetext{
${ }^{1}$ In technological innovation, the term "bleeding edge" refers to businesses that assume a high degree of risk and uncertainty in being the first-movers to bring a product or service to market; see http://www.investopedia.com/terms/b/bleedingedge.asp
}

\section{Motivations}

The motivations for these individuals and groups of farmers to enter the emergent field of commercial urban farming were numerous. The top motivation related to lifestyle-the farmers were able to work close to home, which reduced (or eliminated) commuting time, and allowed them more time with family and friends. The farmers also sought autonomy over their work schedules, and found working outside and engaging in physical activity to be appealing. For example, one farmer in Eva's farm group saw an increased fitness level, achieving "buff arms, without having to go to the gym." Nazanin claimed that picking weeds was therapeutic. Similar health gains were also evident with Sabine, Kim, and members of Marivec's farm group who cycled regularly for tasks associated with their farming business. In addition to contributing positively to health and wellness, urban farmers also enjoyed the self-reliance of growing their own food and the autonomy of being selfemployed. As Kim explained, "My goal is to meet my needs doing something I love that is good for my community and leaves the ecology around me better than I found it." She added that with urban farming, "I don't have work and life. Just life." 


\section{Figure 2. Urban Farm Sites in Metropolitan Vancouver (pins indicate approximate locations)}

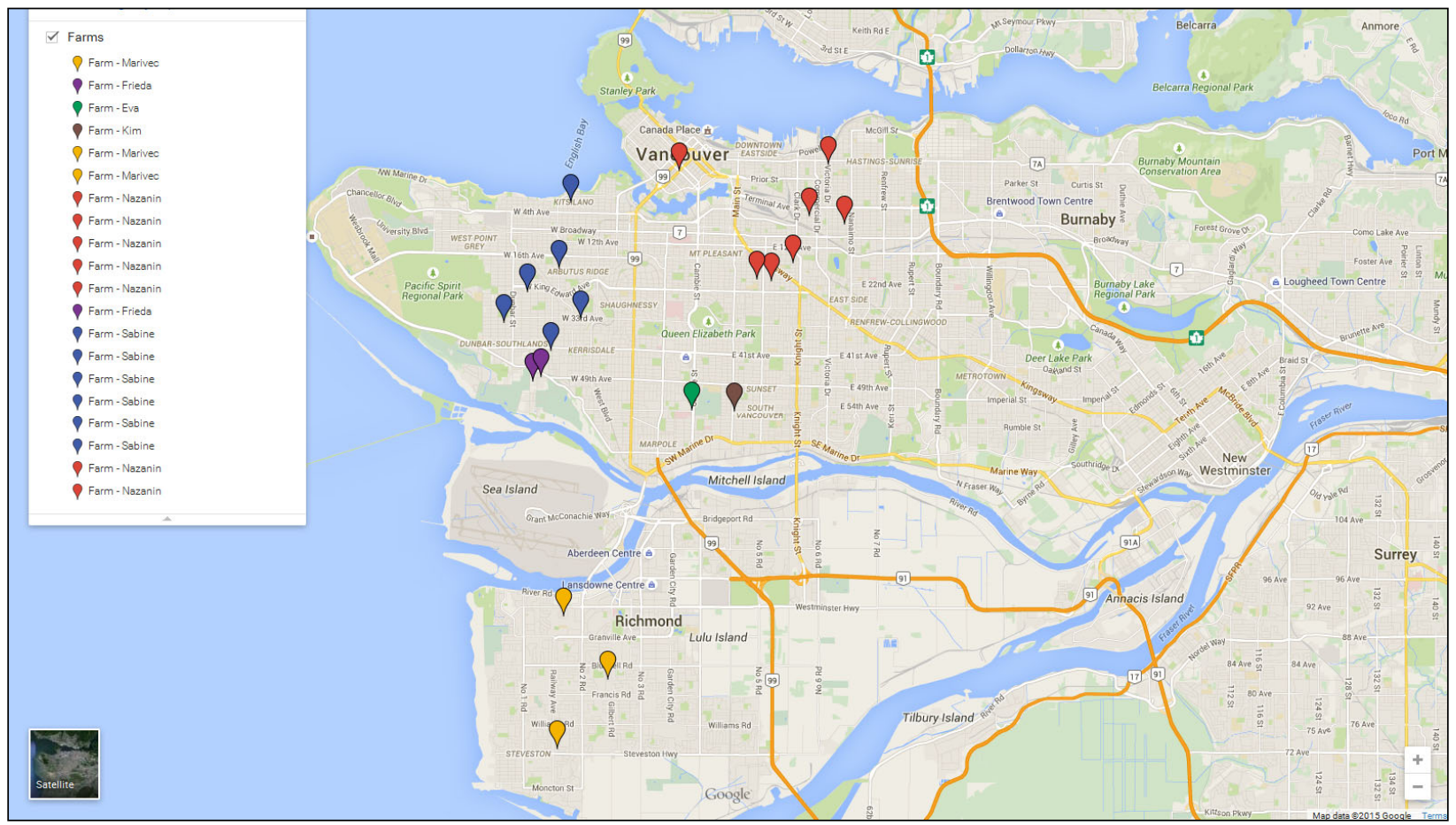

Finally, there was also strong consensus among the urban farmers that they were making positive contributions to the future environmental health of the planet through choosing urban farming as a profession. For example, many of the farmers' business practices revealed a commitment to having low environmental impact. This was demonstrated by them in numerous ways: by using hand tools rather than power tools, choosing bicycles as a primary mode of travel and transport, incorporating food waste into locally gathered compost to improve soil conditions, and practicing organic farming methods. As Kim disclosed, the urban farmers saw themselves and their work as part of a larger ecosystem, one in need of repair: "a big part of what I do is look at how...to make linear streams of production-use-disposal look more like [natural] cycles that are self-renewing. The first step [in this process] was to convert the [unproductive] lawn into usable gardening space." Nazanin expressed a similar motivation, having spent a career working in the landscape industry: "North Americans are crazy about our grass and backyards...spraying fertilizer and grass seed on all of this good soil-most are modified soil, but still good soil- just to have their grass managed." She thought she could "offer a garden service rather than a grass service."

\section{Access to Land}

Interviews with the farmers indicated that access to affordable, high-quality land is paramount to urban farming. The lands used by the urban farmers included existing garden spaces, raised beds, converted lawns (front and back yards), and patio space, primarily on residential property. The size of each farm site ranged from $400 \mathrm{ft}^{2}$ to $10,000 \mathrm{ft}^{2}(37$ $\mathrm{m}^{2}$ to $\left.929 \mathrm{~m}^{2}\right)^{2}$. The urban farmers described desirable farm sites as including some or all of the following physical characteristics:

- Size greater than $400 \mathrm{ft}^{2}$;

- Good sun exposure (usually south facing);

- Contained few weeds and rocks (as removing these was time consuming); and

- Productive soil with high organic matter, good drainage, and used previously for growing garden plants (as opposed to

\footnotetext{
$210,000 \mathrm{ft}^{2}$ is equivalent to about 0.23 acre, or .08 hectare.
} 
recently converted lawn space). It was noted that amending soil was time consuming and costly.

There was minimal concern expressed by the urban farmers about soil contamination, despite research indicating that urban soils commonly contain metallic and organic impurities. The farmers also lacked access to soil maps and surveys to help inform and guide site selection decisions, as these were unavailable in the Vancouver region at this time (Iverson, Krzic, \& Bomke, 2014). When interviewed, many of the farmers explained that their activities weren't taking place on industrial land or near high traffic corridors, areas they considered to carry a higher risk of contamination than residential properties or institutional lawns. Only one farmer, Nazanin, often tested for metals in the soil as part of her site assessment analysis, choosing not to take on sites that were contaminated.

In addition, each urban farmer mentioned that distance from home was an important variable when deciding whether or not to accept land. For example, to keep transportation time and carbon emissions to a minimum, one farmer, Nazanin, took on new sites primarily if they were within a one kilometer $(.62 \mathrm{mi})$ distance from her home; she explained, "I didn't want to drive for hours and hours" between farm sites. Another farmer, Marivec, declined a large site in part because it was too far from her home and the other sites that she farmed.

All of the individuals and groups operated their farms on borrowed land. Only one farmer, Frieda, had a high degree of control over the land she farmed as the property was owned by her immediate family. The farmers used a number of strategies to solicit land from landowners, including conducting media interviews, placing flyers around the community, posting notices online via their own website and others (e.g., CityFarmer and Craigslist), and spreading by word of mouth through other urban farmers and networks of community involvement. Landowners ranged from young professionals with families to single, widowed, or married seniors. According to Marivec's farm group, seniors were the most desirable landowner because they wanted to see their land put to "good use" and didn't need to be educated about the value of growing food since most had home gardens growing up. Seniors also consumed less food from their host site, as compared with other demographics, and they were pleased to have someone take care of their yard and make the property look active, which helped to promote safety and gave the landowner a sense of security. Favorable landowners were also characterized as being "easy-going" and ones who gave autonomy to the urban farmer to decide what should be grown and where to do so on the farm site.

The farmers and landowners created land-use agreements that ranged from one to five seasons; some of these agreements were verbal and thus, informal, while others took the form of written, although not legally binding, contracts. Nazanin and Sabine sought a three-year commitment because of the investment of time and resources required to convert a site into a productive growing space. As farming on borrowed land is tenuous, in that landowners can sell their property or pull out of the agreements at any time, urban farmers did not plan long-term for the sites they managed. For example, Nazanin did not put up permanent structures on the properties she farmed unless the landowners paid for the materials. This idea also extended to the type of food grown on the sites. While the urban farmers grew a plethora of crops, ${ }^{3}$ they tended to steer away from planting slowgrowing, long-living crops on land they did not own, such as fruit trees or asparagus. One farmer and both farm groups also grew flowers (edible and nonedible). In addition, most farmers did not pay for water; this expense was borne by the landowner.

Another feature of the landowner agreements was that no money be exchanged. Nazanin, Sabine, and Marivec's farm group offered their landowners access to the food that was grown on the land they hosted; the owners could either help themselves or receive a full or partial harvest share. Eva's farm group, who managed an institutional site, described

\footnotetext{
${ }^{3}$ Crops grown by the urban farmers included arugula, green beans, fava beans, beets, bok choy, carrots, cauliflower, chickweed, chili peppers, comfrey, corn, cucumbers, dill, eggplant, fennel, garlic, green peppers, kale, leeks, mint, peas, potatoes, squash, Swiss chard, tomatoes, and turnips.
} 
their written agreement as a "classic feudal arrangement" requiring them to provide, in food harvested from the site, the equivalent of $10 \%$ of the revenue to the landowner. Kim, Sabine, Frieda, and Marivec's farm group had verbal agreements with their landowners. However, Sabine later switched to written agreements after losing a farm site after just one year of production. Marivec also considered establishing written agreements after experiencing a landowner who intruded too much in her farm operations (e.g., had strong ideas about what should be planted and over-gleaned produce from the host site, leaving Marivec on occasion without enough produce to sell or include in harvest boxes); however, in the end, she never brought these on. Despite this, both Sabine and Marivec saw written agreements as a better way to manage landowner expectations.

Land agreements between the landowner and urban farmer could be mutually beneficial without the exchange of money. According to the urban farmers, landowners benefited by receiving food, having a maintained yard without paying for a landscaper, and, if they were so inclined, learning about urban farming. For the farmers, having access to lawns and yards in the community to grow food helped reduce their business operation costs, such as transportation and time spent traveling between sites, to markets, and potentially to more distant municipalities where land may be available. It also helped them to remain close to their home and customer base. Despite the tenuous land arrangements and the challenges they pose for urban farmers, there appeared to be no shortage of land available for urban farming, as each farmer was offered more land than they chose to farm.

\section{Growing Techniques and Practices}

There was a consensus among the urban farmers that possessing knowledge of growing techniques was a critical skill for being a successful urban farmer. Five of the six farmers or farm groups contained at least one person with a combination of academic training and work experience in agriculture. The amount of academic training ranged from undergraduate courses in agriculture to the completion of a graduate degree in agriculture. Agriculture-related work experience varied among the farmers: only one farmer grew up on a commercial farm, the remaining five farmers or farm groups did not have direct ties to a farm. One farmer gained experience in small-scale agriculture production by WWOOF-ing. ${ }^{4}$ One farmer did not have any academic training in agriculture when starting her business; she acknowledged that acquiring the appropriate growing knowledge was one of the greatest challenges to urban farming.

All of the urban farmers studied practiced organic growing techniques. This practice, however, did not extend fully to certification. None of them were interested in seeking organic certification; they shared the viewpoint that customers knew them and trusted them to be honest about their practices. Farm visits were extended to customers who wanted to see their operations and learn about their practices first hand.

Achieving good quality soil was important to the farmers. Earthworms were used as one means to improve the quality of the soil, and organic matter was also added. All of the farmers brought in compost from offsite facilities while also producing compost onsite at one or more of their sites. Some farmers added their personal kitchen scraps to the compost. Eva's farm group used grass and leaves collected from the site in the compost. Nazanin composted weeds, and plants which had finished producing marketable products. Only Marivec's farm group actively solicited organic matter offsite to add to their compost; they collected (at no cost to them) approximately $100 \mathrm{lbs}$. $(45 \mathrm{~kg})$ per week of organic kitchen scraps from a local café, soy mash from a local factory, and coffee bean chaff from a local roaster. Alpha pellets, as a nitrogen source, were purchased from a local feed mill to balance the carbon to nitrogen ratio of the compost. None of the farmers intentionally used composting worms, preferring instead to have the compost mature naturally using the sun's heat.

They also practiced organic pest control methods, choosing not to use pesticides to control

\footnotetext{
${ }^{4}$ WWOOF-ing refers to participating in the World Wide Opportunities on Organic Farms, a volunteer-based program where individuals gain experience working on organic farms worldwide (WWOOF Canada, n.d.). Positions range from a few weeks to many months.
} 
insects nor herbicides to control weeds. When pests were first noticed, they were either removed or killed by hand. On occasion, traps were used; for instance, Nazanin used a sugar water and meat trap to catch wasps. Marivec's farm group experimented with companion planting mustard with lettuce to keep another pest, wireworm, off the lettuce plants. It was observed that plots at higher elevations (e.g., on patios) experienced fewer pests. Weeds were controlled mostly through handpicking, employing crop rotation, and using bark mulch.

All of the farmers used starter plants to extend the growing season and maximize the amount of food produced. Starter plants were grown from seed in a protective, controlled environment such as a greenhouse or growing room, providing conditions which optimized sunlight, warmth, and moisture. When these plants displayed hardiness, they were transplanted into the bed. Additionally, all farmers used a type of cold frame to extend the growing season, growing plants such as beets, peppers, and lettuce.

Five of the six individuals or groups practiced intensive growing techniques. Most farmers had two or more plantings of fast-growing crops (leafy greens, spinach, radishes, some herbs) per plot, per season. Once plants had produced their last harvest, most farmers removed them immediately and replaced them with other crops. Kim demonstrated the least intensive practices, allowing plants to go to seed and spread without interference from the farmer. Slow-growing crops, such as potatoes or garlic that can only be harvested once per season, were favored by farmers for their popularity, and in the case of garlic, high value.

All of the farmers watered their plots at least once per day, and often more depending on the plants and time of year. Sprinklers and drip systems were common irrigation tools. All but one farmer used timers on their irrigation systems; this freed the farmer and the landowner from the obligation to water the plants and provided the farmer with an efficiency to direct their time toward other tasks. One farmer chose to water by hand, citing the cost of timers and irrigation equipment to be too expensive. This task consumed two hours of her time each day.

\section{Marketing Strategies}

The urban farmers and farm groups used harvest share (CSA) programs and Vancouver-based farmers markets as the main marketing channels to sell their produce. Nazanin, Sabine, and Marivec's farm group grew primarily for a harvest share program then offered and sold any surplus produce at farmers markets. According to Marivec, it was a straight-forward choice: "We were so busy with other lives (work, kids), we would have gotten a higher return going to farmers markets. But farmers markets take a lot of prep work and consume a full Saturday with selling. With harvest shares, you know there is a home for all of your produce, it was easier to do it that way." Kim directed all of her produce toward harvest shares as she found farmers markets to be too regulated an environment in which to participate. She reported that "the farmers market system in Vancouver is geared toward bigger operations, and toward appeasing the city bureaucracy with all its permits, rules, and inspections. It takes so much energy to deal with all that stuff that it squeezes out really small producers like me." Frieda initially grew primarily for farmers markets and directed excess produce not sold at market to supply her harvest shares.

There were variations in how the farmers organized their harvest share programs. Five of the six urban farmers or farm groups offered a weekly harvest share program, similar to those found in community supported agriculture projects. ${ }^{5}$

A seasonal harvest share subscription ranged in price from $C A \$ 400$ to $C A \$ 750$ for a 20 -week period between May and October. Kim required that her customers pay a CA $\$ 100$ deposit at the beginning of the season to help offset her initial planting costs; subscribers then paid the balance in CA $\$ 30$ instalments weekly as the produce was delivered. Two other farmers, Marivec and Frieda, charged their customers $C A \$ 20$ and CA $\$ 30$ per weekly share, and Marivec sold a double share for $\mathrm{CA} \$ 50$. One farmer reported that through a har-

\footnotetext{
${ }^{5}$ In community supported agriculture projects, customers buy a share in the farm's harvest. The amount of produce they receive depends on the bounty of the harvest in a given season, and thus the customer and farmer share in the risks associated with the growing season.
} 
vest share program, it was easier to sell produce for a price that reflected the true cost of bringing the produce to the marketplace. She remarked, "It's hard to sell a three-dollar head of lettuce to some customers at the [farmers] market. In the harvest share box, it is 'disguised."

The number of harvest share subscriptions varied between the farmers. Nazanin had enough customers to do two sets of weekly subscriptions, and confessed that harvesting twice per week "was a lot of work." Each set initially contained 15 subscriptions, and as Nazanin took on additional sites, she increased these to 20 per set. Subscribers collected their harvest share from Nazanin's home. Sabine had six subscriptions, but grew enough produce that she could have supported up to 20. The remaining farmers who participated in a harvest share program had between one and five subscriptions per week. Frieda expected her neighbors to participate more strongly as harvest share subscribers and was surprised when they showed little interest in purchasing a share. Instead, most of her harvest shares were sold to residents in more distant neighborhoods across the city.

To ensure that their patrons received the freshest quality of produce, the farmers harvested produce as close to the harvest share pick-up or delivery date/time as possible. Nazanin picked most of the products within hours or minutes of the pick-up. Sabine picked anywhere from a few hours to two to three days in advance as she had access to a refrigerator to cool her produce; this allowed her to harvest at an earlier point without sacrificing the quality of the produce she offered.

In addition to harvest share programs, the urban farmers also sold their fresh produce at area farmers markets. Farmers markets represented secondary retailing avenues as they were considered time consuming entities with large overhead costs and no guarantee of sales. When produce was destined for a farmers market, it required cleaning, preparation (e.g., greens needed to be bundled and standardized), and potentially refrigeration and packaging; this was due to the stronger emphasis placed on product presentation at farmers markets. Farmers also had to construct price lists and be present at market for at least six hours per market day, and often more. They were also required by market organizers to select dates for attending markets well in advance of knowing what the growing season would yield and when, diminishing the flexibility to tailor their participation around their production schedule.

Aside from the time investment, farmers markets also required a financial investment in order to participate. For example, market fees for the season ranged from $C A \$ 800$ to $C A \$ 3,000$ per farmer, paid up front in advance of the season. They also required the farmers to source banners, tents, and tables, which can be expensive. The farmers reported that at a farmers market, it took longer to recoup the expenses they had to pay in advance, as monetary transactions are very small (i.e., only a few dollars per transaction). For Kim, "the cost of the market was completely prohibitive - a market table cost a third of what I was making each week."

The revenue generated by urban farmers at farmers markets ranged from $C A \$ 180$ to $C A \$ 500$ per market day depending on the time of season, the variety and volume of produce offered for sale, and whether the person(s) staffing the vendor booth (be it a farmer or volunteer) had an introverted or extroverted personality. Nazanin and Sabine occasionally shared stall space; this helped them overcome two barriers facing small-scale farmers by having enough produce to fill a large stall they might not fill individually and reducing somewhat the cost of participation.

Farmers markets represented competitive environments for farmers in general, and for urban farmers in particular. Urban farmers considered their competition to be small-scale rural organic farmers, who were able to offer higher volumes and greater variety of local produce for sale. The urban farmers also reported price sensitivity among farmers market shoppers. For example, Frieda received comments from customers that some of her produce was priced too high. However, the urban farmers also saw farmers markets as valuable places to solicit harvest share subscriptions and advertise the full spectrum of their businesses (e.g., workshops, farm tours), as Nazanin, Sabine, and Marivec's farm group did. Frieda initially started selling solely through farmers markets, however, by mid-season, she decided to offer harvest shares in 
addition to attending the farmers market. While Frieda experimented with harvest shares in subsequent seasons, she ultimately discontinued them, citing them as a "pain in the ass" to organize. She instead lent the land-a $1,500 \mathrm{ft}^{2}\left(139 \mathrm{~m}^{2}\right)$ plot- to a newer entrant to urban farming to use in their CSA program in exchange for help around the farm. Frieda also passed her harvest share patrons on to this urban farmer. Eva's farm group sold their produce only at farmers markets in 2009, but began arranging harvest share subscriptions from 2010 onward, including to a local school interested in incorporating local food into their home economics curriculum and to a local church for use in their food bank program. The change in their marketing strategy came about when they realized that their farm site held strategic advantage being located in the heart of the city of Vancouver. Eva's group saw customers coming to their farm site (versus the farm group going to them, as in a farmers market model) as an opportunity to establish a "deeper, richer relationship" with their customers. It was a successful strategy as they tripled their harvest share subscription program from 12 clients in 2009 to 36 shares in 2013. While the subscription service became their primary marketing avenue, Eva's farm group continued to use farmers markets as secondary spaces to retail their produce through the 2014 season; they were the only urban farming operation among the studied farmers and farm groups that still relied on farmers markets for revenue generation when surveyed in 2014.

In addition to selling produce through harvest shares and at farmers markets, urban farmers also explored other retailing opportunities. Frieda, Kim, and one farmer in Eva's farm group dabbled in selling produce directly from a stand at their farm sites with limited success. Another farmer conducted sales using an honesty box system where produce was placed outside unsupervised with a suggested price displayed, and customers left money they deemed appropriate in a box provided by the farmer. The farmer noted that there was no theft from the honesty box and believed this was a good way to sell extra produce without an additional time commitment. These retailing initiatives were experimental in nature and carried few expectations on behalf of the farmer; any revenue generated was welcomed.

Sabine and Frieda also sold their produce into pocket markets in the 2009 season. Pocket markets represented small-scale portable local food markets where nonprofit organizations act as local food brokers, purchasing food from area farmers and selling it to urban consumers on their behalf (Evans \& Miewald, 2010). Pocket markets offered the benefit of bulk sales and a lower time commitment from the farmer.

Nazanin experimented with selling to wholesalers; she reported that "they paid a fair price for produce, but you didn't get paid for 90 days, so that was kind of a hassle." Marivec's group solicited restaurants with their excess produce. This action led to a local coffee shop taking on a weekly harvest share and one restaurant asking them to grow specific produce (a particular varietal of radish, alternative greens, edible weeds). Marivec sold this specialized produce to the restaurant at a higher price as these items couldn't be directed into harvest share boxes.

In order to generate sales, all of the urban farmers advertised their business. Websites and blogs were used to communicate the details of their harvest share programs, the dates and locations of the farmers markets they attended, and news about what was growing at the farm sites. Social media marketing was only used by two of the urban farmers. Marivec used Twitter to update her customers about the operations of the business and to educate her customers about the positive social and environmental implications of urban farming. Kim additionally used her blog as a discussion forum about urban farming.

The farmers indicated that word of mouth was an effective means for promoting and attracting business and, in the instance of Marivec's farm group, mitigated paying for advertisements. Only one farmer paid for advertising, taking out ads in local newspapers, such as the Georgia Strait, and in a transit pamphlet called the TransLink Buzzer. The farmers also took advantage of opportunities to speak at local events and festivals and viewed these as opportunities to advertise their business, inform audiences about urban farming practices, promote harvest shares, and, on occasion, sell 
products directly to attendees.

Many of the urban farmers also participated in media interviews and these resulted in greater public exposure for the farmers as a result. For example, after an interview with a prominent media outlet was published, Nazanin received many offers from landowners of land to farm. When advertising their business, there were three attributes which all the farmers promoted: firstly, the localness of their produce, because everything was grown in metropolitan Vancouver; secondly, the freshness of the produce, since it was harvested within the last few hours or days; and thirdly, the low carbon footprint of their operations. These attributes added value to the produce being sold.

All six farmers and farm group leaders highlighted the low carbon footprint of their business. Low carbon practices included using hand tools, cycling to farm sites and to markets, composting, not using refrigeration for harvested products, organic growing, rainwater conservation, and reusing materials or using recycled materials for infrastructure. Eva's farm group, working with a nonprofit cycling organization, delivered the produce to market by bicycle. The delivery services were free as the nonprofit organization was paid by a grant for its services. Sabine travelled by bicycle between all her farm sites.

\section{Revenue/Income Streams}

Most farming households in Canada rely on nonfarm or off-farm income to ensure their economic well-being, and urban farming is no different (Jetté-Nantel, Freshwater, Beaulieu, \& Katchova, 2011). The gross revenue from the farming activities varied between farmers. One farmer estimated CA $\$ 25,000$ on $8,000 \mathrm{ft}^{2}\left(743 \mathrm{~m}^{2}\right)$; while another, less experienced farmer, estimated CA $\$ 60,000$ on one acre $\left(43,560 \mathrm{ft}^{2}, 4,046 \mathrm{~m}^{2}\right)$. Gross revenue per average farm site was similar for Nazanin and Kim; Nazanin estimated CA $\$ 3,000$ per average site ( 400 to $600 \mathrm{ft}^{2}, 37$ to $55 \mathrm{~m}^{2}$ ), and Kim approximated CA $\$ 3,500$ per $400 \mathrm{ft}^{2}\left(37 \mathrm{~m}^{2}\right)$.

To cover the startup expenses, the farmers invested personal money in their operations. This ranged from $C A \$ 100$ to $C A \$ 1,000$ within a farm group to thousands of dollars by individual farmers. The urban farmers reported that most of the investment was recouped by the second year of production through the profits of their operations.

Growing inputs, such as fertilizers and seeds, were a significant expense for Marivec, whose farm group bought seeds in bulk and stored them in a freezer; Sabine; and Kim. Irrigation infrastructure, (removable, above ground) was one of the main expenses for Marivec and Nazanin; its nonpermanent nature meant it could be easily moved to other farm sites.

Eva and Frieda noted wages as their top expense. Most of the farmers commented on the desirability of having additional labor support; however, they added paid staff selectively. This was due to the time needed to train a new hire and the additional expenses beyond wages that might come as a result, such as increased insurance costs for vehicles that the employee would operate. On occasion, some of the farmers took on volunteers to assist with land clearing, bed preparation, building infrastructure, transplanting, picking weeds, harvesting crops, and, periodically, selling produce. Not all farmers were interested in volunteer assistance. Nazanin explained that volunteers were too hit and miss: "Sometimes they'd weed out the wrong thing in the garden; if it was rainy, they wouldn't show up; if it was nice, they would go to the beach. They'd also expect something in return - for example, education, and rightly so-so that took up more of your time." Frieda found volunteers to be largely "unproductive" and instead preferred to have paid staff who were skilled and engaged in their work. Sabine felt she was too disorganized to accept volunteers. One farmer, in Eva's farm group, said they preferred financial donations and guaranteed customers (markets) than volunteer support. Despite this, Eva's group experimented with running a volunteer intern program in 2012 and 2013, recruiting three to five people each year "who had time and would work for vegetables," committing one day per week at the farm. In 2013, they hosted and provided mentorship to eight UBC Farm practicum students who took over the harvest share operations throughout the eight-month season. Having interns with some experience helped compensate for the departure of one member of Eva's farm group at the end of the 2012 season. 
In addition to farming, four of the six farmers or farm groups were also involved in incomegenerating projects related to their urban farming business to help make ends meet. Nazanin, Sabine, and Eva felt that urban farming was not financially viable on its own, but only if done in conjunction with other related value-added activities. Eva emphasized, "We can't charge enough for the food we are growing, so we must increase the valueadded side of the business."

Workshops were the primary means of additional income generation. Nazanin, Frieda, and Kim offered workshops to recreational gardeners, prospective urban farmers, and even tourists. These workshops often included farm tours and covered topics such as permaculture, raising chickens in the city, growing food for personal consumption, and growing food for market.

Beyond workshops, the urban farmers also explored other means of generating additional income. For example, Nazanin offered garden consultations for CA $\$ 90$ for urbanites interested in converting their yards into food-producing spaces; these services included advisory, planning, design, and construction, especially of raised beds using high-end construction materials. Nazanin noted that these efforts, however, were largely in vain: "the consulting work would pay off if it turned into paid work, but it never did."

Eva's farm group constructed ten community garden plots at their farm site as a means of connecting the community to the farm. They charged CA $\$ 60$ per plot and used the revenue generated to offset the cost of materials such as wood boxes and soil; in the end this project broke even. Eva reported that she had a greater demand for garden plots than plots available to rent; this was a reality echoed by community garden organizers across metropolitan Vancouver.

Frieda earned extra monies at a less busy time of year by offering field trips of her pumpkin patch to K-7 school classes. These tours proved popular and were expanded in subsequent years to meet word-of-mouth demand. In 2014, Frieda welcomed 90 groups - three per day - to the pumpkin patch.

Additionally, Frieda acquired (with a family member) a large lot residential property with an orchard of approximately 20 trees on one section of the property. The land was used to grow apples, pears, and soft fruits and provided additional space for related income generators, such as tours, summer camps, and workshops. Despite Frieda's initial motivation to generate income solely from farming, it was these income generators, especially those related to educational programming, which made up $85 \%$ of the money she earned from her urban farming enterprise.

Marivec considered establishing incomegenerating projects (e.g., conducting lectures on how to operate a small farm, targeting individuals interested in small-scale, peri-urban farming), however, her farm group decided to instead direct their time and energies toward earning more money from the land they farmed. For example, they made better crop choices by planting higher value crops, and, with the exception of tomatoes, crops that would mature in a maximum of 60 days so they could turn them under and replant, with a goal of three crop plantings per season.

Kim reported that "growing revenue was never a priority" as she "always had enough." During her brief urban farming tenure, Kim was hesitant to increase her business; she believed that, historically, as rural farmers increased their businesses, they took on more work, but did not necessarily earn more income as a result.

It was evident throughout the study that income-generating projects were seen as important, even critical, components of an urban farming enterprise. They provided the urban farmers with (much needed) additional income while offering value-added services connected with their farming enterprise.

Three farmers, Frieda, Kim, and Nazanin, earned a living solely from their urban farming business; that is, they did not have jobs off the farm to supplement their annual income. However, only one of the farmers studied lived on her own; the farming business was her only source of household income for the entire year. Two other farmers lived in households where at least one other family member contributed to the household income through holding a job "off the farm," which helped with household expenses.

For Frieda, farming the land on which she lived, and that was under her control, was an 
important component of being able to make a living from urban farming. She reported that it developed into a lifestyle: "My whole life is the farm."

Kim noted that her "financial needs were very, very small as I operate as much outside of the money economy as I can. With no car, no cell phone, not desiring to spend money on things like consumer goods and expensive entertainment, as well as sharing an inexpensive rental with three to five other people, I never needed much money." For her, "farming in Vancouver ... was a way to keep the landlord and the bill collectors off my back so that I could get on with living my life without having to do some pointless task making some boss richer so he can throw me some crumbs at the end of the day for doing the work that he makes money off of."

The other farmer, Sabine, and members of both Marivec and Eva's farm groups held part-time or full-time jobs either in the off-season or throughout the entire year in order to supplement the income they earned from urban farming. For example, Sabine did graphic design contract work in the off-season. The farmers in Marivec's farm group held part-time or full-time jobs during the entire year (mechanical engineer, teacher, and civic employee), which contributed to the majority of the income they earned for the year. Marivec's farm group indicated that their business model could only work because each member had a job flexible enough (i.e., a nonstandard work week) that allowed the group to meet together every Thursday and Friday to plant and harvest. Eva earned her on-farm income from one grant to another. She was successful in receiving grants to initially coordinate the farm group, to establish a horticultural therapy program in 2011 (in conjunction with the facility where their farm is sited), and to develop a garden where a dozen low-income families could learn to grow, harvest, and cook from the garden. Eva noted that this was part of a larger strategy to create a community-integrated urban farm. To supplement her income, Eva also worked part-time two days per week off-farm, doing film-related work. The other members of Eva's farm group either held part-time servicesector jobs over the winter months or spent time raising their young families.

Most of the farmers claimed that one of the greatest challenges to urban farming was generating enough revenue to pay themselves a decent wage after all the expenses were paid. One farmer worked out her average wage throughout the season to be $C A \$ 1.60$ per hour. Marivec explained that for her group, "the goal wasn't to make money - we got in it to figure out how to farmthe biggest goal was to not lose money doing it, to break even." She admitted that the one year they made a profit, they were "busting our guts." Nazanin echoed this sentiment, stating that her best year of urban farming-pocketing CA $\$ 30,000$ after paying bills, taxes, and salaries-was when she was working "flat out." Nazanin also spoke of the challenge in finding income in the off-season, adding that the "seasonality of [urban farming] was driving [her] nuts." Eva reported that for her farm group, there "wasn't a strong sentiment about making money," yet they were mindful that the space they farmed (for their harvest share subscriptions) could only support the equivalent of one full-time position.

\section{Leaving the Urban Farm}

Several farmers in this study have since left urban farming (see Table 2). Sabine wound down her enterprise after several seasons, resigning that "just selling produce isn't working." For Nazanin, it was a big summer vacation being planned, combined with the feeling of "spinning your wheels at the end of the day" that prompted her to stop farming. She added "you work hard, look at how much money you made, and it didn't amount to much." She reflected: "I felt like a sharecropper, working the land but not making any money from it. Working a 10,000 $\mathrm{ft}^{2}\left[929 \mathrm{~m}^{2}\right]$ plot is fine for one's own self, but it was too much, in the end to manage so many different plots—-tenants moving in, they'd see your hose and use it...having dogs and cats digging up the garden... it all accumulated over time." Nazanin reported that some of the properties she farmed were passed on to other urban farmers, some she let go of altogether as "the people were just too crazy [i.e., unpredictable] to deal with," and some were taken over by the property owners themselves-some of whom kept the 
Table 2. Status of the Participating Urban Farmers in 2014

\begin{tabular}{|c|c|c|c|}
\hline $\begin{array}{l}\text { Farmer / } \\
\text { Farm Group }\end{array}$ & $\begin{array}{l}\text { Number of } \\
\text { Farmers } \\
\text { Involved in } \\
\text { Organization } \\
\text { in } 2009\end{array}$ & $\begin{array}{c}\text { Still } \\
\text { Farming? }\end{array}$ & Key Factors Explaining 2014 Farming Situation \\
\hline $\begin{array}{l}\text { Eva's farm } \\
\text { group }\end{array}$ & 5 & Yes & $\begin{array}{l}\text { - Most of original group continued to farm on institutional farm site. } \\
\text { - Group refined their practices to centralize most aspects of their urban farming } \\
\text { business, especially the growing and marketing of food, from their farm site. } \\
\text { - Income generators (e.g., community garden plots, horticultural therapy program) } \\
\text { were introduced and expanded over time. } \\
\text { - Part-time jobs held off-farm helped group members to supplement on-farm } \\
\text { income. }\end{array}$ \\
\hline $\begin{array}{l}\text { Marivec's } \\
\text { farm group }\end{array}$ & 3 & Yes & $\begin{array}{l}\text { - Farm group leader, Marivec, purchased land on Vancouver Island and left group } \\
\text { to farm in a more rural setting where she would have control of the land. } \\
\text { - Remaining two farmers continued to farm as a group, but downsized their } \\
\text { operations to one large site, as a response. } \\
\text { - Farming on borrowed land and inefficiencies of working on and across multiple } \\
\text { farm sites contributed to farm leader's exit and rightsizing of farm site to meet } \\
\text { needs of remaining group members. } \\
\text { - Part-time jobs held off-farm helped group members to supplement on-farm } \\
\text { income. }\end{array}$ \\
\hline Frieda & 1 & Yes & $\begin{array}{l}\text { - Secured an additional property. } \\
\text { - Expanded operations beyond farming (e.g., educational programming, } \\
\text { workshops); generated more income from associated side ventures than from } \\
\text { farming. } \\
\text { - Transferred farming portion of work to another urban farmer. } \\
\text { - Was able to make a living solely from income earned on-farm and through related } \\
\text { revenue-generating activities. }\end{array}$ \\
\hline Nazanin & 1 & No & $\begin{array}{l}\text { - Was able to make a living from urban farming, but financial compensation was } \\
\text { low. } \\
\text { - Income earned from income generators (e.g., workshops, consulting activities) } \\
\text { was limited, and securing work in the off-season proved challenging. } \\
\text { - Lack of efficiency working on and across multiple farm sites, ones not under her } \\
\text { direct control, took its toll over time. }\end{array}$ \\
\hline Sabine & 1 & No & Unknown. \\
\hline Kim & 1 & No & $\begin{array}{l}\text { Disenfranchised with food movement in Vancouver; moved to Sunshine Coast, } \\
\text { British Columbia, to farm in a rural setting. }\end{array}$ \\
\hline
\end{tabular}

land in production for personal consumption, while others didn't (for example, one owner built a garage over the farm site).

Kim left urban farming, and the Lower Mainland, following the 2009 season, relocating to the Sunshine Coast of British Columbia to farm in a more rural environment. She expressed disenchantment with the direction that the urban farming movement had taken in Vancouver, calling it "just another fluffy window dressing for the existing unsustainable paradigm." She explained that "urban farming had become a fad...yet another way for university-educated middle-class white folks to get a bigger share for themselves of the money, space, and resources of the city without putting their work in solidarity with the struggles of folks who are displaced by the rampant development and gentrification of Vancouver. This deepens inequalities in access to land, to food, to livelihood, and it adds fuel to the fire that is burning up all hope of an ecologically sustainable city. It saddens me, and it angers me." The site that Kim was 
farming in Vancouver remains in production, although the food products grown are used only for personal consumption by the individuals renting the property.

Marivec purchased a property to farm on Vancouver Island in 2012. In looking forward to having control of her own land, she reflected on the challenges that her group experienced with urban farming: "Running around between plots, it takes up so much brain space, keeping track of the sequence of things - getting product at one plot that needs to be secured ahead of cutting another, watering (put the water on, go do another [task], then forget that you had the water still running...); dealing with odd land owners that have weird, quirky things about the control of the land; [and] not having the time and space to rest the land (crop cover, manure) as every square inch needed to be in production." Marivec noted that two remaining members of her farm group decided not to bring on another farmer to replace her as "they got along well, and it was hard enough to farm, let alone bring other personalities on board." They also downsized their operations to farm one 2,000 $\mathrm{ft}^{2}\left(185 \mathrm{~m}^{2}\right)$ site, and service a smaller number (five to six) of harvest share subscriptions.

\section{Conclusion}

In 2009, urban farming — taking land traditionally zoned for residential, commercial, or institutional use and repurposing it into intensive foodproducing spaces where grown food is primarily offered for sale — was a largely nascent activity in metropolitan Vancouver. Those on the bleeding edge, the six individuals and groups studied here and pioneering this work, saw it as an opportunity to use unproductive lands to enhance the local food supply, sold what they grew through relationship-based retailing arrangements, and sought lifestyle benefits by choosing urban farming as a profession.

However, our study revealed that for half of the urban farmers, the lifestyle benefits they anticipated didn't materialize, despite evolving their approaches and practices as they engaged further in this work. Much like rural farming, urban farming offers an environment in which it is challenging to earn a living. These small-scale growers of highly perishable, non-nutrient-dense, high-cost, lowvalue produce experienced difficulty making ends meet solely from growing and marketing local food. Many of the urban farmers thus supplemented these efforts with value-added income generators, and/or relied on off-farm employment to supplement their annual earnings. Despite this, mounting small-scale commercial urban farming enterprises remained financially tenuous for many of them. Some self-exploitation was evident in their practices as they tested and refined components of their business models to find a successful combination of farming practices, marketing strategies, and related income generators that would allow them to make a living through urban farming, thus achieving the lifestyle benefits they sought by pursuing this work. Many of the farmers also lived in households where other members contributed to the household income from off-farm jobs, which helped to lighten the risk of their participation in urban farming.

Five years after the initial study, only one urban farmer (Frieda) and two farm groups (Eva and Marivec's reconstituted group) were still in operation. Kim and Marivec were farming on the Sunshine Coast and Vancouver Island, respectively. Two other urban farmers, Sabine and Nazanin, left urban farming altogether.

Our study revealed that the farm groups were able to withstand the challenges of urban farming more so than individual farmers. The one successful solo farmer had control of the land she farmed, which afforded her a degree of security to arrange her business enterprise as she needed. Another attribute that contributed to the success of these farmers was the large size of the spaces they farmed and that they farmed fewer sites than most of the unsuccessful farmers. They were also able to adjust their business models to take advantage of income generators and value-added activities, which helped reduce the risk of relying on selling produce alone and further reinforced urban farming as a multifunctional activity. Members of the farm groups also relied on part-time jobs off-farm to provide predictable incomes rather than relying solely on the proceeds of urban farming; this also worked to reduce the risk of engaging in this activity. 
While this initial group of entrepreneurialists experienced mixed results in establishing and growing their urban farming enterprises, this has not diminished people's interest in working toward a more localized food system in metropolitan Vancouver. The total number of urban farming operations has increased more than threefold since 2009 to include 21 urban farming operations as of 2015. This further emphasizes the important role that these early initiators of urban farming had in advertising and educating others about local food and emergent trends, thus "encouraging the diffusion of local growing" (Newman, 2008).

\section{Recommendations}

As the appetite for local food continues to grow in metropolitan Vancouver, urban farming can fill a niche. However, a more comprehensive analysis of the economic realities of small-scale commercial urban farming is needed to better understand why some enterprises succeed while others flounder, and to determine how and if these commercial enterprises can become financially self-sustaining over the long term. Due to land tenure constraints, small-scale commercial urban farmers grew mostly highly perishable, high-cost, low-value vegetables, yet how might the economic viability of their work change if farmers could invest long-term in cultivating high-value fruit crops, honey, and meat products? Other research questions relate to the work undertaken by individuals and groups, teasing out the dynamics of individual vs. group organizations, and the type and size of land parcels that they have access to farm. More research might add further insight into who can withstand, and perhaps overcome, the burdens associated with smallscale commercial urban farming and help us better understand what resources should be mobilized to help these agriculturalists find success. Scholars also highlight the noneconomic value associated with urban farming, so quantifying and tracking these contributions would better reveal the true impact of this work.

There is also a concern in the literature, and echoed throughout this study, about the selfexploitative nature of small-scale commercial urban farming, both to the farmers as paid labor and to the volunteers and interns who trade their time and labor for mentorship, education, and skills development. It raises questions, aptly summarized by Angotti, and still being reconciled within the scholarship about whether "the small bunch of enthusiastic volunteer farmers [will] give way to a new generation of underpaid peons? Can unpaid labor be regenerative without being exploitive?" (Angotti, 2015, p. 339).

Further research is also needed to explore the degree to which these enterprises can move beyond the narrow white, middle-class demographic that largely initiates and supports local food and alternate food networks (Newman, 2008; Vickery, 2014), and be more transformative through reaching a broader citizenry. As Newman suggests, "if the concept of local food production and consumption is to be a viable alternative to industrial food production for more than a few members of a community, it must demonstrate this ability to the broader population; it must be an example of the process of sustainable development at work" (Newman, 2008, p. 40). This step also provides an opportunity to evaluate whether a cultural shift is taking place over time in metropolitan Vancouver and elsewhere. This shift is away from people being what Wendell Berry characterizes as "passive, uncritical, and dependent" consumers of food (Wilkins, 2005, p. 269), and toward practicing food citizenship where "consumers move beyond [mere food] shopping to a broader engagement with the food system in its many dimensions" (Wilkins, 2005, quoting the Polson Institute for Global Development, 2003, p. 7).

Cohen and Reynolds, in their study of urban agriculturalists in New York City, New York, highlight that "many urban agriculture programs and the organizations that run them, require substantial resources to remain viable and provide the multifunctional benefits that practitioners and supporters hope to achieve" (2015, p. 103). To that end, what resources can cities offer to better support the work of urban farmers (e.g., facilitating access to larger plots of land to capture operating efficiencies and incorporate value-added activities, or embedding and supporting urban farming in local and regional plans and policies)? Over the past 20 years, many studies have urged the city of 
Vancouver to more strongly support food producing entrepreneurialists: from Robert Barrs advocating urban gardening as a for-profit venture (Barrs, 1997), the adoption of a motion in July 2003 to support a 'just and sustainable' food system (Mendes, 2006), the city's own 2005 Vancouver Food System Assessment report recommending an entrepreneurial approach to urban agriculture be taken to encourage social enterprise development (Barbolet et al., 2005), the inventorying of 77 potential sites available in the city suitable for (commercial) urban agriculture (Kaethler, 2006), to the city's 2013 adoption of the Vancouver Food Strategy with identified goals including connections with the green economy and increasing neighborhood-level food assets (City of Vancouver, 2013). Yet the city of Vancouver continues to proceed cautiously in supporting the commercialization of urban agriculture more broadly and urban farming more specifically. This uncertainty extends to the policy and regulatory environment. For example, urban farming was only acknowledged as a legitimate activity in the city through zoning bylaw amendments enacted in March 2016. These bylaws, however, placed restrictions on what may be grown (fruits and vegetables only), where sales may take place (e.g., limited to institutional land in areas zoned for residential use), and what could be sold (restricted to what was grown onsite) (City of Vancouver, 2016a; City of Vancouver, 2016b). Compliance with these regulations would have proved problematic for many farmers in our study, especially those who harvested from multiple properties to fill the subscriptions they offered to the public, some of which also included value-added products such as edible and nonedible flowers, and where onsite sales took place on land zoned for residential use. Walker characterizes this hesitation to demonstrate fuller support for urban farming as an example of the city engaging only selectively with the urban agriculture movement (Walker, 2015, p. 7). This is a different approach than is provided by the city of Victoria, British Columbia, for example, where growing food on both public and private lands is a goal embedded in their Official Community Plan (City of Victoria, 2012, updated October 1, 2015) and, effective September 2016, is a per- mitted use in all land-use zones of the city (City of Victoria, 2016).

This reinforces a broader point raised by Angotti in his study of New York City, that municipal (and in metropolitan Vancouver's case, municipal and regional) governments must move beyond "incremental reforms" where "public interventions in the food system [are] largely geared towards changing consumption patterns instead of increasing local food production" (Angotti, 2015, p. 338). He recommends that "efforts to scale-up local food production need to learn from these community-based practices" and see initiatives such as using city-owned land for urban agriculture and providing tax incentives to private landowners who lend their land for urban farming as examples where city governments can move more aggressively (Angotti, 2015, p. 338).

But cities aren't the only actors whose resources need mobilizing for urban farming to achieve successful outcomes. As Cohen and Reynolds recognized in their Five Borough Farms research, to achieve the broader goals set out by urban agriculturalists requires "the support of government and networks of practitioners, nonprofit organizations, and philanthropies" (2015, p. 103). How might these networks and coalitions (and including the private sector) be activated, so that urban farming may also contribute a solution to other urban challenges around climate change, resiliency, transportation, economic development, livability, health, and social inclusion, while also meeting imperatives of public education and engagement of citizens? As McClintock argues, "promoting the growth and vitality of these agricultural spaces through coordinated policy, planning and action across scales-from individual decision-making to municipal planning to national and global policy- "takes us one step closer to the "creation and protection of a new agrarian commons," and works to reduce the "“antithesis between town and country,' intellectual and manual labor, humans and nature" (McClintock, 2010, pp. 203-204). Doing so will also help recognize and value agri-food as an important urban system (Travaline, 2008). It is to these wider ends that small-scale commercial urban farming has a place in the future of our cities. 


\section{Acknowledgements}

The authors would like to thank the urban farmers under study for giving generously of their time and insight so that we may understand the motivations, practices, challenges, and rewards associated with reintegrating local food systems into our urban environments. Thanks also to Peter V. Hall, Duncan Hilchey, and the anonymous JAFSCD reviewers for their constructive feedback on earlier versions of this paper.

\section{References}

Ackerman-Leist, P. (2013). Rebuilding the foodshed: How to create local, sustainable, and secure food systems. White River Junction, Vermont: Chelsea Green.

Alden, D. (2008, October 22). Farmers markets growing in popularity; shoppers interested in reducing their carbon footprint and connecting with local suppliers. Delta Optimist.

Angotti, T. (2015). Urban agriculture: Long-term strategy or impossible dream? Lessons from Prospect Farm in Brooklyn, New York. Public Health, 129(4), 336-341. http://dx.doi.org/10.1016/j.puhe.2014.12.008

Barbolet, H., Cuddeford, V., Jeffries, F., Korstad, H., Kurbis, S., Mark, S., . . . Moreland, F. (2005). Vancouver food system assessment. Retrieved from https://foodsecurecanada.org/resourcesnews/resources-research/vancouver-food-systemassessment

Barrs, R. (1997). Sustainable urban food production in the city of $V$ ancouver: An analytical and strategy framework for planners and decision-makers. City Farmer Urban Agriculture Notes. Retrieved from http://www.cityfarmer.org/barrsUAvanc.html

Blay-Palmer, A., \& Donald, B. (2006). A tale of three tomatoes: The new food economy in Toronto, Canada. Economic Geography, 82(4), 383-399. http://dx.doi.org/10.1111/j.1944-8287.2006. tb00322.x

B.C. Stats. (n.d.-a). Population estimates. Retrieved July 6, 2014, from http://bcstats.gov.bc.ca/Statistics BySubject/Demography/PopulationEstimates.aspx

B.C. Stats. (n.d.-b). Reference maps. Retrieved July 6, 2014 , from http://bcstats.gov.bc.ca/StatisticsBySubject/ Geography/ReferenceMaps/RDs.aspx

City of Vancouver. (2013). What feeds us: Vancouver food strategy. Vancouver, British Columbia: Vancouver Food Policy Council. Retrieved from http://vancouver.ca/people-programs/ empowered-residents.aspx

City of Vancouver. (2016a). Amendments to roning and development by-law and business license by-law regarding urban farming (RTS 11150). Retrieved from http://council.vancouver.ca/20160223/documents Lp1.pdf

City of Vancouver. (2016b). Urban farm guidelines. Retrieved from http://vancouver.ca/peopleprograms/growing-food-for-sale.aspx

City of Victoria. (2016, September 8). Victoria City Council meeting. Retrieved from https://victoria.civicweb.net/filepro/documents

City of Victoria. (2012, updated October 1, 2015). Official community plan. Retrieved from http://www.victoria.ca/assets/Departments/ Planning Development/Community $\sim$ Planning/ OCP $/$ OCP $\% 20$ Book.pdf

Cohen, N., \& Reynolds, K. (2015). Resource needs for a socially just and sustainable urban agriculture system: Lessons from New York City. Renewable Agriculture and Food Systems, 30(1), 103-114. http://dx.doi.org/10.1017/S1742170514000210

Davis, K. (2002). Green roof inventory: Preface report for the Greater Vancouver Regional District.

Evans, T. L., \& Miewald, C. (2010). Assessing the pocket market model for growing the local food movement: A case study of metropolitan Vancouver. Journal of Agriculture, Food Systems, and Community Development, 1(2), 129-144. http://dx.doi.org/10.5304/jafscd.2010.012.011

Hinrichs, C. (2000). Embeddedness and local food systems: Notes on two types of direct agricultural market. Journal of Rural Studies, 16(3), 295-303. http://dx.doi.org/10.1016/S0743-0167(99)00063-7

Houston, J. (2001). Analysis of food growing potential for pilot block in Vancouver. City Farmer Urban Agriculture Notes. Retrieved from http://www.cityfarmer.org/aerialVancouver.html

Iverson, M., Krzic, M., \& Bomke, A. (2014). A framework for site assessment guides for urban impacted soils: A Vancouver case study. Journal of Agriculture, Food Systems, and Community Development, 5(1), 75-85. http://dx.doi.org/10.5304/jafscd.2014.051.006

Jarosz, L. (2008). The city in the country: Growing alternative food networks in metropolitan areas. Journal of Rural Studies, 24(3), 231-244. http://dx.doi.org/10.1016/j.jrurstud.2007.10.002 
Jetté-Nantel, S., Freshwater, D., Beaulieu, M., \& Katchova, A. (2011). Farm income variability and offfarm diversification in Canadian agriculture. Retrieved from the Statistics Canada website: http://www.statcan.gc.ca/pub/21-601-m/21-601m2011093-eng.pdf

Kaethler, T. (2006). Growing space: The potential for urban agriculture in the city of $V$ ancouver (Master's thesis). Retrieved from https://foodsecurecanada.org/sites/foodsecurecan ada.org/files/Growing Space Rpt.pdf

Kaufman, J., \& Bailkey, M. (2000). Farming inside cities: Entrepreneurial urban agriculture in the United States (Working Paper WP00JK1). Cambridge, Massachusetts: Lincoln Institute of Land Policy.

Kaufman, J., \& Bailkey, M. (2001, January). Farming inside cities. Land Lines, 13(1). Retrieved from http://www.lincolninst.edu/pubs/261 FarmingInside-Cities

Levenston, M., Blecha, J., Schendel, K., \& Houston, J. (2001). City farmer uses the latest aerial photos to find out how much food is grown in the city of Vancouver. City Farmer Urban Agriculture Notes.

Retrieved from http://www.cityfarmer.org/aerialVancouver.html

McClintock, N. (2010). Why farm the city? Theorizing urban agriculture through a lens of metabolic rift. Cambridge Journal of Regions, Economy and Society, 3(2), 191-207. http://dx.doi.org/10.1093/cjres/rsq005

McClintock, N., Miewald, C., \& McCann, E. (in press). The politics of urban agriculture: Sustainability, governance, and contestation. In A. Jonas, B. Miller, \& D. Wilson (Eds.), SAGE Handbook on Spaces of Urban Politics. Thousand Oaks, California: SAGE.
Mendes, W. (2006). Creating a 'just and sustainable' food system in the city of $V$ ancouver: The role of governance, partnerships and policy-making (Doctoral dissertation). Retrieved from http://summit.sfu.ca/item/2279

Newman, L. (2008). Extreme local food: Two case studies in assisted urban small plot intensive agriculture. Environments Journal, 36(1), 33-43. Retrieved from http://jps.library.utoronto.ca/ index.php/ejis/article/view/9702

UBC Farm. (n.d.). About the UBC Farm. Retrieved September 30, 2010, from http://ubcfarm.ubc.ca/about/

Vickery, K. K. (2014). Barriers and opportunities for commercial urban farming: Case studies from Austin, Texas and New Orleans, Louisiana (Master's thesis). University of Texas at Austin. Retrieved from https://repositories.lib.utexas.edu/handle/ 2152/26500

Vitiello, D., \& Wolf-Powers, L. (2014). Growing food to grow cities? The potential of agriculture for economic and community development in the United States. Community Development Journal, 49(4), 508-523. https://dx.doi.org/10.1093/cdj/bst087

Walker, S. (2015). Urban agriculture and the sustainability fix in Vancouver and Detroit. Urban Geography, 37(2), 163-182. http://dx.doi.org/10.1080/02723638.2015.1056606

Wilkins, J. (2005). Eating right here: Moving from consumer to food citizen. Agriculture and Human Values, 22, 269-273. http://dx.doi.org/10.1007/s10460-005-6042-4

WWOOF Canada. (n.d.). What is WWOOF? Retrieved March 14, 2017, from https://www.wwoof.ca/about/what-wwoof 